\title{
Clinical evaluation of coronally advanced flap with acellular dermal matrix graft or connective tissue graft in the treatment of gingival recession with thin periodontal phenotype: study protocol for a split- mouth randomized controlled trial
}

Yalin Zhan

Peking University School of Stomatology

Miaozhen Wang

Peking University School of Stomatology

Xiaojing Cao

Peking University School of Stomatology

Feng Liu ( $\nabla$ dentistliufeng@126.com )

Peking University School of Stomatology

Study protocol

Keywords: Acellular dermal matrix, Connective tissue graft, Gingival recession, Root coverage

Posted Date: October 1st, 2020

DOI: https://doi.org/10.21203/rs.3.rs-32870/v1

License: (c) (i) This work is licensed under a Creative Commons Attribution 4.0 International License.

Read Full License 


\section{Abstract}

\section{Background}

Among all mucogingival deformities, gingival recession is one of the most prevalent conditions that demand surgical correction. Accordingly, root coverage procedures are essential parts of plastic periodontal surgeries. It is undeniable that autogenous tissue grafts remain the gold standard for root coverage procedures. Substantial evidences have identified that the connective tissue graft (CTG) combined with coronally advanced flap (CAF) achieves favorable root coverage of recession. Nevertheless, there are some noticeable disadvantages of harvesting autogenous tissue, such as postoperative bleeding, pain, or discomfort at the donor site, restricted tissue supply, increased morbidity, and longer operative duration. In order to overcome the drawbacks of autogenous tissue harvesting, several non-vital substitutes have been produced as alternative options for replacing connective tissue graft. Acellular dermal matrix (ADM) is an allograft derived from human skin, which has been used extensively in various areas of dental practice over the last two decades. ADM exhibits undamaged collagen and elastin matrices that has been used as a substitute for connective tissue for root coverage procedures. Although its clinical efficacy has been discussed in several reviews, conclusions about the application of this material are still unclear and controversial. Moreover, the level of evidence on the clinical outcomes and patient-reported outcomes relevant to ADM graft (ADMG) is low. Therefore, the objective of this split-mouth; randomized, controlled, clinical study is to compare the long-term clinical efficacy of ADMG combination with CAF on root coverage, aesthetics and patient satisfaction with CTG combination with CAF for gingival recession with thin periodontal phenotype, hoping to provide some reference to dentists.

\section{Methods/design}

Forty participants with bilateral Miller Class I/II gingival recession randomly received ADMG (test group) on one side and CTG (control group) on the contralateral side in conjunction with CAF. Gingival recession depth (GRD), gingival recession width (GRW), keratinized tissue width (KTW) are measured at baseline, 2, $4,12,24,48$ and 96 weeks. Mean root coverage (MRC), complete root coverage (CRC), root coverage aesthetic score (RES), color change $(\Delta \mathrm{E})$, and patient satisfaction are assessed in postoperative followup.

\section{Discussion}

CAF combined with CTG has been shown as a predictable technique in root coverage. At present, there is limited long-term data evaluating ADM on root coverage, aesthetics and patient satisfaction for the treatment of gingival recession with thin periodontal phenotype. The result of this split-mouth randomized controlled clinical studies is performed to evaluate the long-time efficacy of ADM, particularly when compared to the "gold standard" (CTG), contributing to an advanced treatment strategy of gingival recession with ideal clinical outcome. 


\section{Trial registration}

International Clinical Trials Registry Platform (ICTRP), ID: ChiCTR2000033230. Registered on 25 May 2020, http://www.chictr.org.cn/showproj.aspx?proj=54052

\section{Background}

Gingival recession is defined as the apical migration of gingival margin to the cemento-enamel junction (CEJ) with exposure of the root surface [1, 2]. This is a common feature in populations [3-6], reaching prevalence about $51 \%$ among subjects [7]. Mechanical factors, such as restoration invading the biological width, tooth brushing trauma, piercing trauma, muscle inserts, localized plaque induced inflammatory lesions, and gingival anatomic factors, are the common etiological factors leading to gingival recession $[8,9]$. The coverage of exposed root surfaces has become an important therapeutic issue due to patients' increasing demands, such as dentinal hypersensitivity, aesthetic problems, root erosion, root caries, or hampering plaque removal [10].

Different surgical techniques have been used for root coverage [11-21]. Evidence indicates coronally advanced flap (CAF) as an effective periodontal plastic surgical procedure for the treatment of Miller Class I/II gingival recessions [22-26]. CAF can be used alone [22-24, 27], or in combination with connective tissue grafts (CTG) [25, 28-31], enamel matrix derivatives (EMD) [32], platelet-rich fibrin (PRF) [33], or low intensity laser therapy [34] to improve the technique's predictability. A systematic review [35] revealed that CAF either with or without CTG might lead to predictable complete root coverage (CRC) in the treatment of Miller Class I/II multiple recessions; while combination with CTG appeared to improve the long-term stability of CRC, which is accepted as the gold standard in the treatment of gingival recessions $[27,35,36]$.

Although subepithelial connective tissue procedures provide excellent predictability. This technique, however need for the second surgical site, involves a certain degree of discomfort for the patient, increases the risk of pain and hemorrhage postoperatively. In addition, the amount of graft is limited by the palatal donor site and thickness. In order to overcome the drawbacks of autogenous tissue harvesting, PRF [33], platelet-rich plasma (PRP) [37], EMD [38], xenogeneic collagen matrix (XCM) [39-41], and acellular dermal matrix (ADM) [42, 43], and xenogeneic origin (XADM) [44, 45] have been used as alternative options to the CTG for plastic periodontal and implant surgery.

ADM is a derivative of human dermis, which is processed to remove the cellular and epidermal components, thereby removing the source of disease transmission and immunologic reaction, leaving a structurally intact connective tissue matrix composed of collagen fibrillar network, intact proteins, elastin filaments, proteoglycans and hyaluronan, and basement membrane allow ADM as a scaffold to allow ingrowth of host tissues, thereby giving it characteristics of a feasible soft tissue graft material [46]. It was initial use in the 20th century $[47,48]$. Since that ADM has been used extensively in various areas of dental practice over the last two decades $[49,50]$. The acellular dermal matrix graft (ADMG) has been recommended for the treatment of alveolar ridge deformities [51] to increase the width of keratinized 
tissue around teeth and implants [52-54], for guided bone [55, 56] or tissue regeneration [57], for root coverage procedures $[55,58-60]$, avoiding the disadvantages of autogenous connective tissue. Although the clinical efficacy of ADMG has been discussed in several reviews (i.e., European Federation of Periodontology, American Academy of Periodontology, and Cochrane), the application of this material is still unclear and controversial. Moreover, the evidence level on the long-term clinical outcomes and patient reported outcomes relevant to ADMG are still low.

Periodontal phenotype has also been reported as an important parameter that could influence the clinical outcome of root coverage procedures and the predictability in root coverage [61-65]. In root coverage procedures, the gingival thickness less than $1 \mathrm{~mm}$ could harm the achievement of CRC [66] and might have a greater influence on the final outcome than the influence of keratinized tissue (KT) [62]. Due to ADM's non-vital structure, which depends on cells and blood supply from the recipient site to achieve reorganization, the periodontal phenotype is very critical for the clinical outcome. To the best of our knowledge, no randomized controlled clinical trial has compared the outcomes of CTG versus ADM in treatment of gingival recessions with thin periodontal phenotype. Therefore, the aim of this study was to evaluate the clinical effectiveness of ADMG combination with CAF on root coverage, aesthetics and patient satisfaction compared to CTG combination with CAF for the treatment of Miller Class IXII gingival recessions with thin periodontal phenotype.

\section{Objectives and hypotheses}

The current single-centered, split-mouth, randomized, controlled clinical trial was planned to compare the clinical efficacy of ADMG and CTG in conjunction with CAF in the treatment of Miller class I and II gingival recessions with thin periodontal phenotype.

The primary hypotheses are ADMG and CTG with CAF provides similar amount of root coverage and aesthetic outcome in Miller class I and II gingival recessions. The second hypotheses are the incidence of postoperative complications was higher in CTG.

\section{Methods/design}

\section{Overview}

The study is a prospective single-center, split-mouth, randomized, controlled clinical trial. 40 patients who are with Miller class I and II gingival recessions in need of the coverage of exposed root surfaces. The assessments, interventions, and follow-ups will be performed at First Clinical Division, Peking University School and Hospital of Stomatology (Beijing, China). This study has been approved by the biomedical ethics committee of Peking University School and Hospital of Stomatology (PKUSSIRB-202054029) and registered in International Clinical Trials Registry Platform (ICTRP) under the ID: ChiCTR2000033230.

\section{Inclusion criteria}

The patients are selected according to the following inclusion criteria: 
1. Age $\geq 18$ years;

2. Patients willing to attend the study and provide an informed consent;

3. Systemically healthy and no contraindication for periodontal surgery;

4. Presence of localized bilateral Miller class I or II adjacent gingival recessions $\geq 3 \mathrm{~mm}$ with thin periodontal phenotype in the maxillary or mandibular arches without any clinical sign of active/chronic periodontal disease;

5. Having full-mouth plaque score and full-mouth bleeding score $\leq 15 \%$;

6. No history of surgical intervention in the relevant areas.

\section{Exclusion criteria}

1. Habitual tobacco smoking and/or chewing;

2. Habitual alcohol consumption;

3. Pregnancy or lactating women;

4. Participants having crowns or restorations involving the CEJ or those with nonidentifiable CEJ;

5. Individuals using medications that can interfere with healing and allergic to penicillin.

\section{Recruitment}

Subjects who are looking for the coverage of exposed root surfaces and are willing to join this trial will be recruited from First Clinical Division, Peking University School and Hospital of Stomatology. Subjects will receive the study information. Before subject is included in the present study, the consent form must be signed. Figure 1 shows the procedure of participants through this trial.

\section{Randomization, grouping, and blinding}

The randomization process is performed by a professor in the absence of the working investigators using a software program by a computer-generated randomly permuted block. Allocation is concealed in opaque envelopes until immediately before surgery to determine which sites of gingival recession will receive the test procedure and the contralateral teeth will receive the control procedure. All subjects will be treated by one experienced and calibrated periodontist who do not partake in the allocation, examination, and statistical analysis. The treatment plan and grouping will be confidential to the examiner and statistical analyst. Under postoperative adverse events, unblinding is permissible.

\section{Interventions}

All surgical procedures are performed at the First Clinical Division, Peking University School and Hospital of Stomatology by the same periodontist. Before the surgical procedures, the periodontal status is evaluated; the comprehensive clinical examination is performed; and the etiology of the recessions is determined for each eligible participant by a calibrated examiner. Identified etiological factors are eliminated; detailed oral hygiene instructions $(\mathrm{OHI})$ are given; and full-mouth supragingival scaling and 
tooth polishing are performed. Surgical procedures are initiated at least 4 weeks after the final appointment in which the inclusion criteria are re-evaluated and the good oral hygiene is approved.

The surgeries are performed by an experienced periodontist who has been calibrated before the trial. Both test and control surgeries are performed at the same clinical appointment. The same surgical procedure is used for both groups, except that control sites received the ADMG (test group), while contralateral sites received the CTG (control group). Following local anesthesia, a coronally advanced flap design is performed in all cases as described by Zucchelli previously [67]. Briefly, an intracrevicular incision is made through the bottom of the crevice. Two mesial and distal vertical releasing incisions are made including both papillae adjacent to the area of gingival recession. The papillaes in the surgical site are deepithelialised by interdental incisions considering as anatomic papilla. The flap is elevated with a splitfull-split approach in the apico-coronal direction and the soft tissue apical to the root exposures is elevated in a full-thickness manner to facilitate the highest possible thickness of the flap to cover the recession area. Finally, the apical part of the flap is raised in a split-thickness manner to release residual muscle tension and to facilitate the flap passively positioned over the CEJ without tension. Following flap elevation, the exposed root surface was gently planed with sharp curets (Gracey Curettes, Hu-Friedy, Chicago, Illinois).

The control group then received CTG obtained from the palate as previously described [28]. The connective tissue is trimmed to a shape and size designed to cover the root surface and the surrounding bone. The thickness of graft is $1 \mathrm{~mm}$.

The exposed root surface of the test group is treated with an ADM that is aseptically rehydrated in sterile saline, according to the manufacturer's instructions. The graft is trimmed to a shape and size designed to cover the root surface and the surrounding bone. The basement membrane side is placed adjacent to bone and tooth, and the connective tissue side is placed facing the flap, according to Harris [68]. The thickness of graft is $1 \mathrm{~mm}$.

Both the ADM and CT cover the recipient area at the level of CEJ on the coronal site and get over the vascular tissues $3 \mathrm{~mm}$ on the lateral and the apical borders of the recession defect. The grafts in both groups are secured on interdental areas and on lateral sites using 6-0 bioabsorbable sutures. The CAF is then positioned $1 \mathrm{~mm}$ coronally to the CEJ and covered the total graft surfaces in both groups. The CAF is sutured stress free at this position using 6-0 non-absorbable sutures, which are also used to secure the donor site. Microsurgical hand instruments (Hu-Friedy, Chicago, Illinois) and $\times 4.0$ loupe (Q Optics, Texas) are used in all surgical procedures. No periodontal dressing is utilized.

All patients are instructed to discontinue tooth brushing and to avoid trauma or pressure at the surgical site. A $0.12 \%$ chlorhexidine digluconate gargle is prescribed 3 times daily for 14 days, and amoxicillin (500 mg, tid) was prescribed for 7 days.

The sutures are removed after 14 days, and the patients are instructed to clean the surgical sites with a $0.12 \%$ chlorhexidine digluconate gargle 3 times daily for 14 days. After this period, they will resume 
mechanical tooth cleaning of the treated areas using a soft toothbrush and a careful roll technique. During the follow-up recalls, oral hygiene instructions are reinforced and professional tooth cleaning is performed if needed.

\section{Examination}

\section{Baseline examination}

Individual acrylic stents are prepared to use as the reference points to align the probe properly, and to ensure reproducibility during reevaluation examinations.

Clinical parameters including plaque index (PLI) [69], gingival index (GI) [70], probing depth (PD), clinical attachment level (CAL), gingival recession depth (GRD), gingival recession width (GRW), and keratinized tissue width (KTW) are measured using a periodontal probe (PCP-UNC 15; Hu-Friedy Manufacturing, Chicago, IL, USA) and rounded to the nearest $0.5 \mathrm{~mm}$ by a calibrated examiner (not the therapist), who has been trained to adequate levels of accuracy and reproducibility. Thin phenotype decision is given after gingival thickness (GT) measurement as described by Ahmedbeyli [71].

\section{Examination during the follow-ups}

\section{Follow-up}

All subjects will be recalled for follow-up at weeks 2, 4, 12, 24, 48 and 96 after the surgery. We will like to make a phone call to remind participants to promote complete follow-up. At weeks 4, 12, 24, 48 and 96 after the surgery, PLI, GI, PD, CAL, GRD, GRW, KTW, periodontal phenotype and the color measurements using an intraoral spectrophotometer (SpectroShade, Medical High Technologies) will be examined by a calibrated examiner. Aesthetic outcomes are evaluated using the Root Coverage Esthetic Score (RES) [72].

Patient satisfaction is assessed using a Visual Analogue Scale/Score (VAS) [73, 74]. Each patient is questioned about his/her satisfaction with regard to the following patient-centred criteria: root coverage; gingival colour, shape and contour; surgical procedure in terms of pain and discomfort related to the duration of the procedure; post-surgical phase in terms of the pain, swelling and post-operative complications.

\section{Primary parameters}

The primary parameters of this trial are mean root coverage (MRC), CRC, KTW, RES, and color change $(\Delta \mathrm{E})$. MRC percentage is calculated as [(GRD baseline-GRD 12, 24, 48, 96 weeks)/GRD baseline] $\times 100 \%$. CRC is evaluated at tooth level and is calculated as the percentage of teeth with gingival recession having complete coverage achieved as the gingival margin at or over CEJ [(Teeth with CRC)/(All treated teeth)] $\mathrm{x}$ $100 \%$.

\section{Secondary parameters}


The secondary parameters of this trial are PD, CAL, and VAS scale to patient satisfaction.

\section{Sample size}

The sample size of this trial is calculated based on the formula: $\mathrm{N}=\left[\frac{\left(\frac{z_{2}}{2}+z \beta\right) \sigma}{\delta}\right] 2\left(\frac{1}{Q^{1}}+\frac{1}{Q^{2}}\right)$. According to the preliminary experiment results and data analysis from currently published articles, the mean difference of the reduction in gingival recession $(\delta)$ is around $0.1 \mathrm{~mm}$ and the standard deviation in groups $(\sigma)$ is around $0.3 \mathrm{~mm}$.

If the inspection level ( $\alpha$ ) is set at 0.05 and the power of test $(\beta)$ is set at $90 \%$, then 36 subjects will be required for each group. Given a loss to follow-up is around $10 \%$, this study will require 40 subjects for each group.

\section{Timeline}

The recruitment began in June 2020, and the intervention period will be ending in June 2023. Figure 2 shows the schedule of enrollment, intervention, and assessments.

\section{Data collection and management}

The data of the patients will be documented both on spreadsheets and databases. The statistical analysis will be performed by two experimenters independently. The data monitoring committee is composited. There is not competing interests in the data monitoring committee.

\section{Statistical analysis}

The statistical analysis will be performed using a software program (SPSS version 22; SPSS, USA). The distribution of the variables was validated by D'Agostino-Pearson omnibus normality test and parametric tests are used for inter- and intra-group comparisons. Paired $t$ test was used for inter-group comparisons of $\mathrm{PI}, \mathrm{GI}, \mathrm{PD}, \mathrm{CAL}, \mathrm{GRD}, \mathrm{GRW}, \mathrm{KTW}$ and the changes of these parameters. Intragroup comparisons for the same variables are done using repeated measures one-way ANOVA test and followed by Bonferroni correction for post hoc multiple comparisons. The number of teeth with MRC and CRC between groups were compared using Fisher's exact test. Multiple imputation will be used to handle missing data. Twotailed p-values $<0.05$ are considered statistically significant. Data analyses will be performed by SPSS software.

\section{Ethical considerations}

\section{Ethical approval}

The trial has been approved by the biomedical ethics committee of Peking University School and Hospital of Stomatology (PKUSSIRB-202054029). Before subjects are officially recruited into this study, they will 
be given a study information and will be asked to sign the consent form. During the trial, any important protocol modifications will communicate to relevant parties.

\section{Withdrawal}

Subjects will be informed that they have the right to withdraw from this trial at any time without providing a reason. If the withdrawal occurs, treatment will also be provided to the subject. Under postoperative adverse events, discontinuing intervention for a given trial participant is permissible.

\section{Dissemination of results}

The results of this trial will be saved at International Clinical Trials Registry Platform (ICTRP) and published in an international peer-reviewed journal which will allow for anyone access to obtain the results.

\section{Discussion}

Several graft substitute materials for CTG and surgical techniques have been investigated for treating gingival recession [75-78]. Studies have shown that root coverage with ADM increased the coverage of exposed root and the thickness of the keratinized gingiva compared to when root coverage was attempted without ADM $[79,80]$. Nevertheless, contradictory results were reported when ADM was compared to CTG [79, 81-83].

The long-term results of root coverage procedures have progressively gained interest among clinicians [84-86]. The 20-year outcomes of CAF alone for the treatment of localized gingival recession observed that gingival recession decreased from $68.59 \%$ (at 1 year) to $56.11 \%$ (at 20 years) and the stability of the gingival margin was maintained in $56 \%$ of the treated sites [85]. Similarly, the same authors also reported on the 20-year outcomes of patients treated with CAF + CTG for gingival recession, which found that the addition of a CTG seemed to provide benefits for maintaining the obtained results, as the minimal changes in MRC were noted over the 20 years' timeframe (from $74.23 \%$ in the first year to $67.69 \%$ at the 20 -year recall) [87]. A similar trend towards the recurrence of gingival recession following root coverage procedures has been reported in the literature $[82,84,85,88]$. Evidence in the literatures is available when evaluating the efficacy of ADM in root coverage procedures in the short-term [89-91]. However, when observed in the long-term, clinical studies demonstrated a significant worsening in the outcomes of root coverage obtained with ADMG over time [79, 82].

This study thus intends to evaluate the long-term outcomes of ADM compare to CTG for treating gingival recessions with thin periodontal phenotype, to the best of our knowledge, have not been previously assessed. We hope that the results could lead to an advanced treatment strategy of gingival recession with ideal clinical outcome.

\section{Trial status}


The trial has been registered at International Clinical Trials Registry Platform (ICTRP), ID: ChiCTR2000033230, registered on 25 May 2020. The recruitment began in June 2020, and the recruitment will be completed in June 2021.

\section{Abbreviations}

ICTRP: International Clinical Trials Registry Platform; CEJ: cemento-enamel junction; CAF: coronally advanced flap; CTG: connective tissue grafts; EMD: enamel matrix derivatives; PRF: platelet-rich fibrin; CRC: complete root coverage; PRP: platelet-rich plasma; XCM: xenogeneic collagen matrix; ADM: acellular dermal matrix either from human; XADM: acellular dermal matrix either from xenogeneic origin; ADMG: acellular dermal matrix graft; MRC: mean root coverage; KT: keratinized tissue; $\mathrm{OHI}$ : oral hygiene instructions; PLI: plaque index; Gl: gingival index; PD: probing depth; CAL: clinical attachment level; GRD: gingival recession depth; GRW: gingival recession width; KTW: keratinized tissue width; GT: gingival thickness; RES: Root Coverage Esthetic Score; VAS: Visual Analogue Scale/Score; $\Delta \mathrm{E}$ : color change; SD: standard deviation.

\section{Declarations}

\section{Acknowledgements}

Not applicable.

\section{Authors' contributions}

$\mathrm{YZ}, \mathrm{MZ}$, and FL conceive the study design and drafted the protocol. XC participates in the recruitment and allocation. $Y Z$ is the major contributor in writing the manuscript. All authors read and approved the final manuscript.

\section{Funding}

This trial was conducted with no funding.

\section{Availability of data and materials}

Not applicable.

\section{Ethics approval and consent to participate}

The trial was approved by the biomedical ethics committee of Peking University School and Hospital of Stomatology (PKUSSIRB-202054029). The trial complies with the Standard Protocol Items:

Recommendations for Interventional Trials (SPIRIT) Checklist. Informed consent will be obtained from all study participants. Before subjects participate in this trial, the consent form must be signed. 
Not applicable.

\section{Competing interests}

The authors declare that they have no competing interests.

\section{References}

1. Tugnait A, Clerehugh V. Gingival recession its significance and management. J Dent. 2001;29:38194. 区

2. Cortellini P, Bissada NF. Mucogingival conditions in the natural dentition: Narrative review, case definitions, and diagnostic considerations. J Periodontol. 2018;89:S204-S213.

3. Wilson RD. Marginal tissue recession in general dental practice: a preliminary study. Int J Periodont Rest. 1983;3:40-53.

4. Serino G, Wennstrom JL, Lindhe J, Eneroth L. The prevalence and distribution of gingival recession in subjects with high standard of oral hygiene. J Clin Periodontol. 1994;21:57-63.

5. Baelum V, Fejerskov O, Karring T. Oral hygiene, gingivitis and periodontal break- down in adult Tanzanians. J Periodontal Res. 1986;21:221-232.

6. Loe $\mathrm{H}$, Anerud A, Boysen $\mathrm{H}$. The natural history of periodontal disease in man: prevalence, severity, and extent of gingival recession. J Periodontol. 1992;63:489-495.

7. Susin C, Haas AN, Oppermann RV, Haugejorden O, Albandar JM. Gingival recession: epidemiology and risk indicators in a representative urban Brazilian population. J Periodontol. 2004;75:13771386 .

8. Kassab M, Cohen R. The etiology and prevalence of gingival recession. J Am Dent Assoc. 2003;134:220-225. ख

9. Khocht A, Simon G, Person P, Denepitiya JL. Gingival recession in rela- tion to history of hard toothbrush use. J Periodontol. 1993;64:900-905. \

10. Paolantonio M, Dolci M, Esposito P, D’Archivio D, Lisanti L, Di Luccio A, Perinetti G. Subpedicle acellular dermal matrix graft and autogenous connective tissue graft in the treatment of gingival recessions: a comparative 1-year clinical study. J Periodontol. 2002;73:1299-1307.

11. Cohen DW, Ross SE. The double papilla positioned flap in periodontal therapy. J Periodontol. 1968;39:65-70.

12. Sullivan HC, Atkins JH. Free autogenous gingival grafts III. Utilization of grafts in the treatment of gingival recessions. Periodontics. 1968;6:152-160.

13. Guinard EA, Caffesse RG. Treatment of localized gingival recessions Part I. Lateral sliding flap. J Periodontol. 1978:49:351-356.

14. Langer B, Langer L. Subepithelial connective tissue graft technique for root coverage. J Periodontol. 1985;56:715-720. 
15. Tarnow DP. Semilunar coronally repositioned flap. J Clin Periodontol. 1986;13: 182-185.

16. Allen EP, Miller PD. Coronal positioning of existing gingiva: short term results in the treatment of shallow marginal tissue recession. J Periodontol. 1989;60:316-319.

17. Pini-Prato G, Pagliaro U, Baldi C, et al. Coronally advanced flap procedure for root coverage Flap with tension versus flap without tesion: a randomized controlled clinical study. J Periodontol. 2000;71:188-201

18. Cordioli G, Mortarino C, Chierico A, Grusovin MG, Majzoub Z. Comparison of 2 techniques of subepithelial connective tissue graft in the treatment of gingival recessions. J Periodontol. 2001;72:1470-1476.

19. Del Pizzo, M, Zucchelli G, Modica F, Villa R, Debernardi C. Coronally advanced flap with and without enamel matrix derivative for root coverage: a 2-year study. J Clin Periodontol. 2005;32:1181-1187.

20. Trombelli L, Minenna L, Farina R, Scabbia, A. Guided tissue regeneration in human gingival recessions A 10-year followup study. J Clin Periodontol. 2005;32:16-20.

21. Pilloni A, Paolantonio M, Camargo PM. Root coverage with a coronally posi- tioned flap used in combination with enamel matrix derivative: 18-month clinical evaluation. J Periodontol. 2006; 77:2031-2039.

22. Zucchelli G, De Sanctis M. Treatment of multiple recession-type defects in patients with esthetic demands. J Periodontol. 2000;71:1506-1514.

23. Zucchelli G, De Sanctis M. Long-term outcome following treatment of multiple Miller Class I and II recession defects in esthetic areas of the mouth. J Periodontol. 2005;76:2286-2292.

24. Zucchelli G, Mele M, Mazzotti C, Marzadori M, Montebugnoli L, De Sanctis M. Coronally advanced flap with and without vertical releasing incisions for the treatment of multiple gingival recessions: a comparative con- trolled randomized clinical trial. J Periodontol. 2009;80:1083-1094.

25. Chambrone L, Lima LA, Pustiglioni FE, Chambrone LA. Systematic review of periodontal plastic surgery in the treatment of multiple recession-type defects. J Can Dent Assoc. 2009;75:203a-203f.

26. Ayub LG, Ramos UD, Reino DM, Grisi MFM, Taba MJ, Souza SLS, Palioto DB, Novaes ABJ. A Randomized comparative clinical study of two surgical procedures to improve root coverage with the acellular dermal matrix graft. J Clin Periodontol. 2012; 39:871-878.

27. Zucchelli G, De Sanctis M. The coronally advanced flap for the treatment of multiple recession defects: a modified surgical approach for the upper anterior teeth. J Int Acad Periodontol. 2007;9:96103.

28. Cetiner D, Bodur A, Uraz A. Expanded mesh connective tissue graft for the treatment of multiple gingival recessions. J Periodontol. 2004;75:1167-1172.

29. Carvalho PF, Da Silva RC, Cury PR, Joly JC. Modified coronally advanced flap associated with a subepithelial connective tissue graft for the treatment of adjacent multiple gingival recessions. J Periodontol. 2006;77:1901-1906.》 
30. Chambrone LA, Chambrone L. Subepithelial connective tissue grafts in the treatment of multiple recession-type defects. J Periodontol. 2006;77:909-916.

31. Pini-Prato GP, Cairo F, Nieri M, Franceschi D, Rotundo R, Cortellini P. Coronally advanced flap versus connective tis- sue graft in the treatment of multiple gingival recessions: a split-mouth study with a 5year follow-up. J Clin Periodontol. 2010;37: 644-650.

32. Cordaro L, Di Torresanto VM, Torsello F. Split-mouth comparison of a coronally advanced flap with or without enamel matrix derivative for coverage of multiple gingival recession defects: 6- and 24month follow-up. Int J Periodont Rest. 2012;32: e10-e20.

33. Aroca S, Keglevich T, Barbieri B, Gera I, Etienne D. Clinical evaluation of a modified coronally advanced flap alone or in combination with a platelet-rich fibrin membrane for the treatment of adjacent multiple gingival recessions: a 6-month study. J Periodontol. 2009;80:244-252.

34. Ozturan S, Durukan SA, Ozcelik O, Seydaoglu G, Haytac MC. Coronally advanced flap adjunct with low intensity laser therapy: a randomized controlled clinical pilot study. J Clin Periodontol. 2011;38:1055-1062.

35. Hofm€anner P, Alessandri R, Laugisch O, Aroca S, Salvi GE, Stavropoulos A, Sculean A. Predictability of surgical techniques used for coverage of multiple adjacent gingival recessions: a systematic review. Quintessence Int. 2012;43:545-554.

36. Chambrone L, Sukekava F, Araújo MG, et al. Root coverage proce- dures for the treatment of recession-type defects. Cochrane Database Syst Rev. 2009;15:CD007161.

37. Shepherd N, Greenwell H, Hill M, Vidal R, Scheetz JP. Root coverage using acellular dermal matrix and comparing a coronally positioned tunnel and without platelet-rich plasma: a pilot study in humans. $\mathrm{J}$ Periodontol. 2009;80:397-404. 『

38. Moses O, Artzi Z, Sculean A, et al. Comparative study of two root coverage procedures: a 24-month follow-up multicenter study. J Periodontol. 2006;77:195-202.

39. McGuire MK, Scheyer ET, Snyder MB. Xenogeneic collagen matrix with coronally advanced flap compared to connective tissue with coronally advanced flap for the treatment of dehiscence-type reces- sion defects. J Periodontol. 2010;81:1108-1117. \

40. Cardaropoli D, Tamagnone L, Roffredo A, Gaveglio L. Treatment of gingival recession defects using coronally advanced flap with a porcine collagen matrix compared to coronally advanced flap with con- nective tissue graft: a randomized controlled clinical trial. J Periodontol. 2012;83:321-328. 『

41. Jepsen K, Stefanini M, Sanz M, et al. Long-term stability of root cov- erage by coronally advanced flap procedures. J Periodontol. 2017;88:1319-1328. 『

42. Aichelmann-Reidy ME, Yukna RA, Evans GH, Nasr HF, Mayer ET. Clinical evaluation of acellular

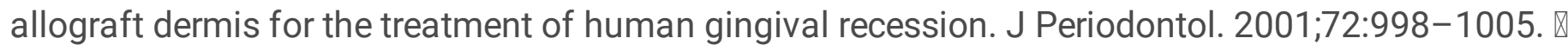

43. Joly JC, Carvalho AM, da Silva RC, Ciotti DL, Cury PR. Root coverage in isolated gingival recessions using autograft versus allograft: a pilot study. J Periodontol. 2007;78:1017-1022. 『

44. Cie slik-Wegemund M, Wierucka-Młynarczyk B, Tanasiewicz M, Gilowski Ł. Tunnel technique with collagen matrix compared with connective tissue graft for treatment of periodontal recession: a ran- 
domized clinical trial. J Periodontol. 2016;87:1436-1443.

45. Pietruska M, Skurska A, Podlewski Ł, Milewski R, Pietruski J. Clinical evaluation of Miller class I and II recessions treatment with the use of modified coronally advanced tunnel technique with either collagen matrix or subepithelial connective tissue graft: a randomized clinical study. J Clin Periodontol. 2019;46:86-95.

46. Allen EP. AlloDerm: an effective alternative to palatal donor tissue for treatment of gingival recession. Dent Today 2006; 25: 48, 50-2; quiz 52.

47. Wainwright DJ. Use of an acellular allograft dermal matrix (AlloDerm) in the management of fullthickness burns. Burns 1995;21: 243-8. $\nabla$

48. Shulman J. Clinical evaluation of an acellular dermal allograft for increasing the zone of attached

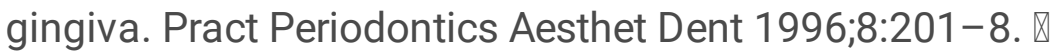

49. Scheyer ET, Sanz M, Dibart S, Greenwell H, John V, Kim DM, Langer L, Neiva R, Ras- perini G. Periodontal soft tissue non-root coverage procedures: a consensus report from the AAP Regeneration Workshop. J Periodontol 2015;86:S73-6. \

50. Chambrone L, Tatakis DN. Periodontal soft tissue root coverage procedures: a systematic review from the AAP Regeneration Workshop. J Periodontol 2015;86(2 Suppl): S8-51. $\nabla$

51. Batista ELJr, Batista FC, Novaes ABJr. Management of soft tissue ridge deformities with acellular dermal matrix. Clinical approach and outcome after 6 months of treatment. J Periodontol. 2001;72:265-273.

52. Wei PC, Laurell L, Geivelis M, Lingen MW, Maddalozzo D. Acellular dermal matrix allografts to achieve increased attached gingiva Part 1. A clinical study. J Periodontol. 2000;71:1297-1305.

53. Wei PC, Laurell L, Lingen MW, Geivelis M. Acellular dermal matrix allografts to achieve increased attached gingiva Part 2. A histological comparative study. J Periodontol. 2002;73:257-265.

54. Yan JJ, Tsai AY, Wong MY, Hou LT. Comparison of acellular dermal graft and palatal autograft in the reconstruction of keratinized gingiva around dental implants: a case report. Int J Periodont Rest. 2006;26:287-292.

55. Novaes ABJr, Souza SLS. Acellular dermal matrix graft as a membrane for guided bone regeneration. A case report. Implant Dent. 2001;10:192-196.

56. Fernandes PG, Novaes ABJr, de Queiroz AC, de Souza SL, Taba MJr, Palioto D. B, Grisi MF. Ridge preservation with acellular dermal matrix and anorganic bone matrix cell-binding peptide P-15 after tooth extraction in humans. J Periodontol. 2011; 82:72-79.

57. Andrade PF, Souza SL, Macedo GO, Novaes ABJr, Grisi MFM, Taba MJr, Palioto DB. Acellular dermal matrix as a membrane for guided tissue regeneration in the treatment of Class II furcation lesions: a histometrical and clinical study in dogs. J Periodontol. 2007;78:1288-1299.

58. Aichelmann-Reidy ME, Yukna RA, Evans GH, Nasr HF, Mayer ET. Clinical evaluation of acellular allograft dermis for the treatment of human gingival recession. J Periodontol. 2001;72:998-1005. 
59. de Queiroz Co`rtes A, Sallum AW, Casati MZ, Nociti FHJr, Sallum EA. A two-year prospective study of coronally positioned flap with or without acellular dermal matrix graft. J Clin Periodontol. 2006:33:683-689.

60. Felipe MEMC, Andrade PF, Grisi MFM, Souza SLS, Taba MJr, Palioto DB, Novaes ABJr. Comparison of two surgical procedures for the use of the acellular dermal matrix graft in the treatment of gingival recessions: a randomized controlled clinical study. J Periodontol. 2007;78:1209-1217.

61. Baldi C, Pini-Prato G, Pagliaro U, Nieri M, Saletta D, Muzzi L, Cortellini P. Coronally advanced flap procedure for root coverage. Is flap thickness a relevant predictor to achieve root coverage? A 19case series. J Periodontol. 1999;70:1077-1084.

62. Woodyard JG, Greenwell H, Hill M, Drisko C, lasella JM, Scheetz J. The clinical effect of acellular dermal matrix on gingival thickness and root coverage compared to coronally positioned flap alone. J Periodontol. 2004;75:44-56.

63. Huang LH, Neiva RE, Wang HL. Factors affecting the outcomes of coronally advanced flap root coverage procedure. J Periodontol. 2005;76:1729-1734.

64. Hwang D, Wang HL. Flap thickness as a predictor of root coverage: a systematic review. J Periodontol. 2006;77:1625-1634.

65. Jepsen K, Jepsen S, Zucchelli G, Stefanini M, deSanctis M, Baldini N, Greven B, Heinz B, Wennstro€m J, Cassel B, Vignoletti F, Sanz M. Treatment of gingival recession defects with a coronally advanced flap and a xenogeneic collagen matrix: a multi-center randomized clinical trial. J Clin Periodontol. 2013;40:82-89.

66. Berlucchi I, Francetti L, Del Fabbro M, Basso M, Weinstein RL. The influence of anatomical features on the outcome of gingival recessions treated with coronally advanced flap and enamel matrix derivative: a 1-year prospective study. J Periodontol. 2005;76:899-907.

67. Sanctis MD, Zucchelli G. Coronally advanced flap: A modified surgical approach for isolated recession-type defects: Three-year results. J Clin Periodontol. 2007;34:262-268.

68. Harris RJ. Root coverage with a connective tissue with partial thickness double pedicle graft and an acellular dermal matrix: A clinical and histological evaluation of a case report. J Periodontol. 1998;69:1305-1311.

69. Silness J, Lö e H. Periodontal disease in pregnancy. II. Correlation between oral hygiene and

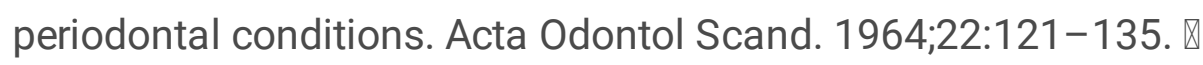

70. Lö e H. The gingival index, the plaque index and the retention index systems. J Periodontol. 1967;38:610-617. $\nabla$

71. Ahmedbeyli C, Sebnem D, Cakar G, et al. Clinical evaluation of coronally advanced flap with or without acellular dermal matrix graft on complete defect coverage for the treatment of multiple gingival recessions with thin tissue biotype. J Clin Periodontol. 2014;41:303-310.

72. Cairo F, Rotundo R, Miller PD, et al. Root Coverage Esthetic Score: A System to Evaluate the Esthetic Outcome of the Treatment of Gingival Recession Through Evaluation of Clinical Cases. J Periodontol. 2009;80:705-710. 
73. Cortellini P, Tonetti M, Baldi C, Francetti L, Rasperini G, Rotundo R, Prato GP. Does placement of a connec- tive tissue graft improve the outcomes of coronally advanced flap for coverage of single gingival recessions in upper anterior teeth? A multi-centre, randomized, double-blind, clinical trial. J Clin Periodontol. 2009:36:68-79.

74. Tonetti MS, Fourmousis I, Suvan J, Cortellini P, Bragger U, Lang NP. European Research Group on Periodontology. Healing, post-operative morbidity and patient perception of out- comes following regenerative therapy of deep intrabony defects. J Clin Periodontol. 2004;31:1092-1098.

75. Cairo F, Cortellini P, Pilloni A, Nieri M, Cincinelli S, Amunni F, Tonetti MS. Clinical efficacy of coronally advanced flap with or without connective tissue graft for the treatment of multiple adjacent gingival recessions in the aesthetic area: A randomized con- trolled clinical trial. J Clin Periodontol. 2016;43:849-856.

76. Pietruska M, Skurska A, Podlewski L, Milewski R, Pietruski J. Clinical evaluation of Miller class I and II recessions treatment with the use of modified coronally advanced tunnel technique with either collagen matrix or subepithelial connective tissue graft: A randomized clinical study. J Clin Periodontol. 2019:46:86-95.

77. Romanos AH, Abou-Arraj RV, Cruz SE, Majzoub ZA. Clinical and patient-centered outcomes following treatment of multiple gingival recessions using acellular dermal matrix allografts. Int J Periodont Rest. 2017;37:843-851.

78. Vincent-Bugnas S, Borie G, Charbit Y. Treatment of multiple maxillary adjacent class I and II gingival recessions with modified coronally advanced tunnel and a new xenogeneic acellular dermal matrix. J Esthet Restor Dent. 2018;30:89-95.

79. Harris RJ. A short-term and long-term comparison of root coverage with an acellular dermal matrix and a subepithelial graft. J Periodontol. 2004;75:734-43.

80. Scarano A, Barros RR, lezzi G et al. Acellular dermal matrix graft for gin- gival augmentation: a preliminary clinical, histologic, and ultrastructural evaluation. J Periodontol. 2009;80:253-9.

81. Barros RR, Macedo GO, de Queiroz AC, Novaes ABJr. A modified surgical flap for root coverage in association with grafting materials. J Esthet Restor Dent. 2015;27: 84-91.

82. Moslemi N, MousaviJazi M, Haghighati F, Morovati SP, Jamali R. Acellular dermal matrix allograft versus subepithelial connec- tive tissue graft in treatment of gingival recessions: A 5-year randomized clinical study. J Clin Periodontol. 2011;38:1122-1129.

83. de Souza SL, Novaes ABJr, Grisi DC, Taba MJr, Grisi MF, de Andrade PF. Comparative clinical study of a subepithelial connective tissue graft and acellular dermal matrix graft for the treatment of gingival recessions: Six- to 12-month changes. Journal of International Academy of Periodontology. 2008;10:87-94.

84. Nickles K, Ratka-Kruger P, Neukranz E, Raetzke P, Eickholz P. Ten-year results after connective tissue grafts and guided tissue regeneration for root coverage. J Periodontol. 2010;81:827-836.

85. Pini Prato GP, Magnani C, Chambrone L. Long-term evaluation (20 years) of the outcomes of coronally advanced flap in the treatment of single recession-type defects. J Periodontol. 
2018:89:265-274.

86. Rasperini G, Acunzo R, Pellegrini G, Pagni G, Tonetti M, Pini Prato GP, Cortellini P. Predictor factors for long-term outcomes stability of coronally advanced flap with or without connective tissue graft in the treatment of single maxillary gingival recessions: 9 years results of a randomized controlled clinical trial. J Clin Periodontol. 2018;45:1107-1117.

87. Pini Prato GP, Franceschi D, Cortellini P, Chambrone L. Long-term evaluation (20 years) of the outcomes of subepithelial connective tissue graft plus coronally advanced flap in the treatment of maxillary single recession-type defects. J Periodontol. 2018;89:1290-1299.

88. Pini Prato G, Rotundo R, Franceschi D, Cairo F, Cortellini P, Nieri M. Fourteen-year outcomes of coronally advanced flap for root coverage: Follow-up from a randomized trial. J Clin Periodontol. 2011;38:715-720.

89. Ayub LG, Ramos UD, Reino DM, Grisi MF, Taba MJr, Souza SL, Novaes ABJr A Randomized comparative clinical study of two surgical procedures to improve root coverage with the acellular dermal matrix graft. J Clin Periodontol. 2012;39:871-878.

90. Ozenci I, Ipci SD, Cakar G, Yilmaz S. Tunnel technique versus coronally advanced flap with acellular dermal matrix graft in the treatment of multiple gingival recessions. J Clin Periodontol. 2015;42:1135-1142.

91. Wang HL, Romanos GE, Geurs NC, Sullivan A, Suarez-Lopez Del Amo F, Eber RM. Comparison of two differently processed acellular dermal matrix products for root coverage procedures: A prospective, randomized multicenter study. J Periodontol. 2014;85;1693-1701.

\section{Figures}




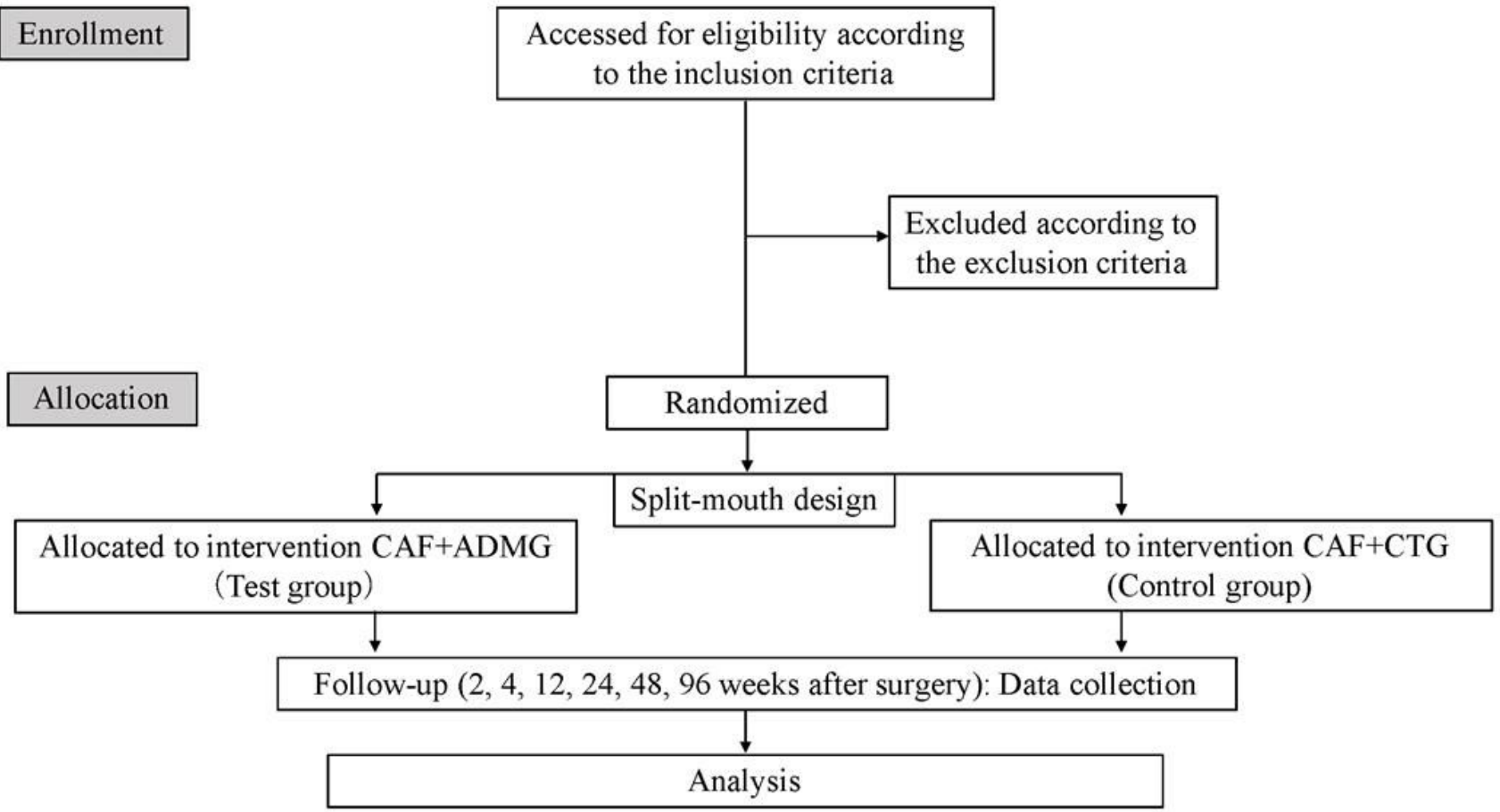

\section{Figure 1}

Consolidated Standards of Reporting Trials (CONSORT) diagram. 


\begin{tabular}{|c|c|c|c|c|c|c|c|c|c|}
\hline \multirow[b]{3}{*}{ TIMEPOINT } & \multirow{3}{*}{$\begin{array}{c}\text { Enrollment } \\
\begin{array}{c}\text { Prior to } \\
\text { Allocation }\end{array}\end{array}$} & \multirow{3}{*}{$\frac{\text { Allocation }}{0}$} & \multicolumn{7}{|c|}{ STUDY PERIOD } \\
\hline & & & \multirow{2}{*}{$\begin{array}{c}\text { Baseline } \\
0\end{array}$} & \multicolumn{6}{|c|}{ Weeks a fter Surgery } \\
\hline & & & & Week 2 & Week 4 & Week 12 & Week 24 & Week 48 & Week 96 \\
\hline $\begin{array}{l}\text { ENROLLMENT: } \\
\text { Eligibility screen }\end{array}$ & $\checkmark$ & & & & & & & & \\
\hline Informed consent & v & & & & & & & & \\
\hline ALLOCATION & & $\checkmark$ & & & & & & & \\
\hline \multicolumn{10}{|l|}{$\begin{array}{r}\text { INTERVENTIONS: } \\
\text { CAF+ADMG }\end{array}$} \\
\hline & & & & & & & & & \\
\hline $\mathrm{CAF}+\mathrm{CTG}$ & & & & 4 & & & & & $\rightarrow$ \\
\hline $\begin{array}{r}\text { ASSESSMENT: } \\
\text { PLI }\end{array}$ & & & v & $v$ & $v$ & v & $v$ & v & $v$ \\
\hline GI & & & v & & $v$ & v & $v$ & $v$ & $v$ \\
\hline PD & & & $v$ & & & & $\mathrm{v}$ & $v$ & $v$ \\
\hline CAL & & & $v$ & & & & $v$ & $v$ & $v$ \\
\hline GRD & & & $v$ & & $v$ & $v$ & $v$ & $v$ & $v$ \\
\hline GRW & & & $v$ & & $v$ & $v$ & $v$ & $v$ & $v$ \\
\hline KTW & & & $v$ & & $v$ & $v$ & $v$ & $v$ & $v$ \\
\hline Periodontal phenotype & & & $v$ & & $v$ & $v$ & $v$ & $v$ & $v$ \\
\hline Color change & & & & & $v$ & $v$ & $v$ & $v$ & $v$ \\
\hline RES & & & & & $v$ & $v$ & $v$ & $v$ & $v$ \\
\hline Patient satisfaction & & & & $v$ & $v$ & $v$ & $v$ & $v$ & $v$ \\
\hline
\end{tabular}

\section{Figure 2}

The schedule of enrolment, intervention, and assessments. Abbreviation: plaque index (PLI), gingival index (GI), probing depth (PD), clinical attachment level (CAL), gingival recession depth $\triangle \mathrm{GRD}$, gingival recession width (GRW), keratinized tissue width (KTW), root coverage esthetic score (RES).

\section{Supplementary Files}

This is a list of supplementary files associated with this preprint. Click to download.

- SPIRIT.doc 